\author{
St ud i a P ilosophic a \\ Wrat is l a vi e n s i a \\ vol. XIV, fasc. 1 (2019) \\ DOI: $10.19195 / 1895-8001.14 .1 .12$
}

\author{
KATARZYNA GURCZYŃSKA-SADY \\ ORCID: 0000-0002-7804-6434 \\ Pedagogical University of Cracow
}

\title{
The Belief in the Existence of a Real Man: Eugenic Myth and its Consequences
}

\begin{abstract}
The first half of the 20th century witnessed the development of the classic eugenics. Some countries in Europe and the USA of different historical past, cultures and degree of development were universally attracted by the eugenic ideology. This raises few questions concerning the basis of its universal attractiveness for masses and its success. This article answers those questions indicating strong (religious-like) belief in the myth which served as a base for the eugenical way of thinking (being older than this thought). This myth narrates a story about the existence of "real people" who lived in the past, yet unfavourable circumstances caused their degradation, but who - with the assistance of physicians (technocrats of the new society) and through medical procedures - may be reborn. This paper aims at the reconstruction of the myth on the basis of the writings of Plato, Campanella and Nietzsche. As examples of its "realization" of the myth, I provide the activities of the institutions like Lebensborn houses in Germany and Nobel Sperm Bank in the USA.
\end{abstract}

Keywords: eugenics, myth, power, weakness, Lebensborn

\section{The Emergence of Eugenics}

The eugenic ideas appeared at the end of the 19th century and have dominated the first half of the 20th century. During this period many eugenic associations were established in Europe and in the United States. Laws enabling the sterilization of people affected by hereditary diseases were introduced, legal acts prohibiting marriages between certain groups (sick or from different races), as well as laws 
prohibiting migration of certain groups of people (e.g., from the south of Europe to the USA due to their "hereditary laziness"). There is factual evidence confirming the universal acceptance of the eugenic practices. This raises several questions: How eugenics became so popular? What was the basis of social support for its policies? What had convinced people of its righteousness?

The policies and their approval were based on the fear for the future of the society which growth of wealth is usually limited by the number of those who are unable or unwilling to contribute to it. ${ }^{1}$ The rising level of population at the end of the 19th and early 20th century was accompanied by the flourishing of charity institutions. On the one hand, the presence of such institution was appreciated, but, on the other, raised the fear of the recession of society which instead of developing and attaining higher levels of material well-being, would be burdened with expenditures on those who cannot (or do not want to) contribute to its well-being.

Concerns about the future development of society are important elements of the so-called social Darwinism, and it is difficult to rebut them. However, it seems that the popularity of the eugenic ideas, like in case of other popular ideas, is based on a myth which is widespread among various peoples. It can be described briefly as the myth of the "real man," a creature living in the distant past who died off due to corruption, but thanks to some effort may be reborn. This article aims at the reconstruction of this myth.

\section{The Founding Myth of Eugenics}

In philosophy one encounters several myths corresponding to the vision of the eugenic paradise. One of them is The City of the Sun, ${ }^{2}$ a vision created by the Renaissance utopian writer Tommaso Campanella. He depicted the life of a community which attains its fullness in earthly life. It is worth emphasizing that this is a utopian vision not only - which is often stressed - when it comes to its social order; it is also utopian as far as the image of man is concerned: his behaviour, feelings, goals and the cultivation of land. Responsibilities are shared equally. There is no remarkable difference in the activities of women and men. They work together, share meals and live together. Their food is supervized by a doctor who makes choices regarding the kinds of meals along with their volume in order to keep Solarians healthy and working efficiently. The doctor's orders also pertain to procreation. Here Campanella stressed the role of a physician who, being a dietitian and a medical practitioner, is also a state officer responsible for matching people. He takes notes about individuals when they exercise naked. Then he pairs them so that they have sexual intercourse

${ }^{1}$ This kind of explanation rooted in fear for the future of society is indicated by many authors writing about the late 19th and early 20th century's eugenic movement. For example, Musielak, in his work on eugenic sterilization, notes: "The popularity of eugenics in the first decades of the 20th century was due to the conviction of many that it was a modern science and that it could solve many difficult social, demographic, and health problems"-M. Musielak, Sterylizacja ludzi ze względów eugenicznych w Stanach Zjednoczonych, Niemczech i w Polsce (1899-1945), Poznań 2008, p. 62; unless otherwise indicated, all citations from Polish have been translated by the Author.

2 T. Campanella, The City of the Sun, transl. D. Donno, The Floating Press 2009. 
(the interval was every third night after a bath). The selection is done in accordance with the principle of compensation. Now, the question is why did he do so?

Campanella claims that procreation is not a matter of private concern. Procreation is primarily for the good of the community, while the happiness of the individuals depends on the good of the community. The basic idea of eugenic thinking is that the well-being of the state depends on its material contents. Therefore, a concern for citizens is nothing but a concern for the species. ${ }^{3}$

The description of life given in The City of the Sun, where everyone is equal and everyone is working physically, raises the question: are some individuals better than other ones? Campanella admits that among the virtuous Solarians there are those who distinguish themselves due to their wisdom. And these are - like in the case of Plato's philosopher- kings - considered worthy to govern and are assigned the role of important state officers. But biologically, this elite is pathological. They are distinguished by the capacity to think yet at the same time it makes them dysfunctional. The process of thinking and being from from the physical exercise weakens their bodies and makes them unfit as future parents. Luckily, Campanella finds a way to compensate for this. The wise men can mate with lively, passionate, and nice women. This coupling shall remove any frailty or defects. It is also worth mentioning that in the City of the Sun all women are beautiful. Due to the recommended activities, they become agile, healthy, slim and firm. Just ready to be loved. But can one follow his heart in such a society?

Campanella recommends those interested in each other to engage in talking, initiating jokes and exchanging flowers. But if their offspring may be born sick, and this is what the doctor is able to predict, the sexual relationship between them is forbidden. As long as a woman is sterile or pregnant with a biologically relevant male - love with another is allowed. So we witness the possibility of love and happiness. There is also a provision that grants the right to the sick and the crippled people to survive without any threat, nobody is allowed to kill them. In spite of their imperfection, they can be useful for activities like brailing the wool, putting down pillows, working as spies for the state and others. ${ }^{4}$

Each Solarian is satisfied, fed and - what is important to the eugenic technocrats - obedient to the king. As an efficient citizen, he works systematically and provides the state with offsprings. Each of them is also a soldier. Practising martial arts is an important element of life in the City of the Sun. The average Solarian is physically fit, brave and courageous. Campanella claims, that soldiering skills prevents emasculation among citizens. ${ }^{5}$

This vision of the ideal state consists of three main interesting themes: procreation for the good of the state, production in farms and readiness to undertake military tasks. All these themes are also present in Plato's vision of the ideal state.

For Plato, the quality of "human material" is linked to the military readiness. There is a designated group of citizens to be soldiers. Soldiers are brave men, un-

\footnotetext{
${ }^{3}$ Ibid., p. 31

${ }^{4}$ Ibid., p. 36.

${ }^{5}$ Ibid., p. 39.
} 
touched by emotional bonds and therefore not attached to anybody for too long. They shed no tears and are completely devoted to the state and its success. They live for honours and rewards, which are offered in the form of sexual gratification. Rewards motivate men and provide the state with "good" offspring. ${ }^{6}$

It is well known that Sparta's system was an important inspiration for Plato's dialogues such as Republic or The Laws which depicted an image of the new world. Sparta was a city (as we know from the work of Plutarch of Chaeronea) completely subordinated to the idea of military power. Spartans evaluated their children immediately after their birth in terms of their suitability to fight in wars. Then they would kill the sick and the weak. The state's policy of procreation was focused on the "production" of soldiers. The success of a man was represented by his strong health and his readiness to fight. He had to be able to hate the enemy and defeat him even at the cost of his own life. Therefore the Spartan par excellence was a fearless warrior. It is important to notice that the strength of the warrior in battle was not only the strength of the human body but also an ability to adopt the right strategy.

The strength needed to defeat the enemy is both physical and intellectual in nature. Therefore, no wonder that for many anthropological descriptions it is one of the central categories for the description of the man.

Among the leading philosophers advocating the concept of strength and power in man is Friedrich Nietzsche. The dichotomy between strength and weakness helped him to divide mankind into masters and slaves. As Nietzsche expresses, the Lord (master) is the one whose physical strength is expressed through the qualities of the spirit such as steadfastness, fearlessness, decisiveness, or ruthlessness. The slave is weak: his physical misery is accompanied by mental traits such as tolerance (the inability to impose his/her opinion on the others), the tendency to compromise (which is a form of cowardice), or being humble (manifested especially clearly in piousness).

By creating this dual and disjointed image of humanity, Nietzsche expands on the category of power and links with the animal world from which, according to him, we came. The bravery of beings as we once were and the power to fight is still within us, despite the process of humanization. However, only a part of mankind preserved quantum of this power in the original state, which remains the essential feature of all living beings. From this point of view, weakness is a pathology, a disease. It is synonymous to the lack of power. ${ }^{7}$

The history of humanity, according to Nietzsche, from the pre-historic to the modern times, is the story of the gradual degeneration of man who lives in society, renouncing his primordial power, but never losing it completely. This gives us hope for the future. Degenerate mankind may overcome its weakness. Human being can be reborn going back to the original condition. ${ }^{8}$ How? According to Nietzsche, the rebirth of mankind can only be accomplished through strong individuals. Their

\footnotetext{
${ }^{6}$ Plato, Republic, transl. B. Jowet, Seattle 2010, 460b.

${ }^{7}$ F. Nietzsche, On Genealogy of Morality, transl. C. Diethe, Cambridge 2007, pp. 23-24.

${ }^{8}$ Ibid., p. 25.
} 
presence gives hope for the future depicted as the revival of forces of life. Ur-people were perfect beings possessing power, being fertile, healthy and resourceful. But they became weak due to unfavourable circumstances. Therefore, the rebirth of mankind may occur via primordial power that "dwells" in man. The power remains "hibernated" in him, but in proper circumstances, it can be "passed on" and provide a basis for the revival of the future generation.

Although Nietzsche, if we look at all of his work, cannot be considered as the enthusiast of eugenics, his history of mankind surely reflects eugenic ideas. The image of a human being as a strong entity which degenerated but is capable of rejuvenation is close to the heart of the eugenic ideology ${ }^{9}$ especially in the Nazi version; the difference being that only that they took his metaphors literally. To revive the "real man" from his "dormant" form became the purpose of Nazi science. For this purpose, they set up an institute aiming at studying the "real" history of the Germans.

\section{The Myth that Came True}

The elite Nazi research institute was founded in 1935. Its official name was the Ahnenerbe Research and Education Society. "Ahnenerbe" signifies "ancestral legacy," and the society aimed at examining it. The institute was founded to acquire knowledge about the ethnic past of the Germans, (their Aryan roots) ${ }^{10}$ and to catalogue their "outstanding" achievements. ${ }^{11}$

The research conducted was supposed to be scientific, but the scientists have created an exaggerated eugenic myth instead. ${ }^{12}$ They have created the national saga of the race of warriors from the north of Europe: tall, slender, strong and resourceful. They were to possess extraordinary physical and spiritual qualities. They were considered to be the creators of the culture of Western civilization. They were said to be inventors of music, art and literature, and endowed with the

${ }^{9}$ As Gawin writes: "Starting from the second half of the 19th century in European culture, politics, science, literature, fascination with the phenomenon of degeneration has been observed. After the defeat of the Spring of Nations heredity became a key word through which various social and political processes were explained. The idea of degeneration found a lively reflection in writings of outstanding intellectuals like Hyppolite Taine, Emil Durkheim, Gustav Le Bon, Cesare Lambros, Friedrich Nietzsche. It appeared also in the novels of Honore de Balzac, Emil Zola and Karol Dickens"-M. Gawin, Rasa i nowoczesność: historia polskiego ruchu eugenicznego (1880-1952), Warszawa 2003, pp. 52-53.

10 The theory of existence of the Aryan race, what is very interesting, does not come directly from the Nazis or even from the Germans. It is derived from studies done in the 18th century mainly by two Englishmen: James Parsons and William Jones. The theme was pursued by Schlegel, who has created an anthropological fairytale about Himalayan man who went west to reach the Nordic countries like Scandinavia and then Germany. This theory, because of its weak scientific basis, without the ideological purpose it was intended to serve, would not find any acceptance.

${ }^{11}$ H. Pringle, Master Plan: Himmler's Scholars and the Holokaust, New York 2007, p. 12.

12 G. Schafft, writing about the Nazis' understanding of the notion of race, notes: "Nobody aspires to conduct research, even if it seems to have no prejudice. In any case, [...] it would not be allowed. The role of racial sociolinguistics has grown. In other words, racial slurs have come to have their priority, and not the research, except when such research was of political importance"-G. Schafft, From Racism to Genocide: Anthropology in the Third Reich, Urbana-Chicago 2004, pp. 217-218. 
"spark of genius" which they passed from generation to generation. And most of the Germans possess this "spark." 13 Therefore the task of Germany was to bring it out, protect and multiply the spark. To bring it out meant to extract, or to identify the bearers of the "spark." To protect meant not to allow ethnic Aryans to mix with other races. To multiply meant to encourage the selected specimens to engage in the process of reproduction. This challenge was propagated by the slogan advocating saving Western European civilization from the downfall.

A number of well-known actions have been taken to realize the postulates. A group of highly respected individuals - SS-men - was created. It was forbidden by law for Aryans to mix with non-Aryans. Many national groups were eradicated as not worthy of the reproduction. Especially Jews were considered a threat to the race since they occupied the lowest position in the Nazi ethnic hierarchy. They were carriers of the "Jewish germ," a peculiar reverse of the "sparks of genius" in the Aryans. ${ }^{14}$

These actions were justified in the name of the myth of the true man: a healthy, prolific, industrious and courageous warrior, capable of facing the unfavourable history. History of Germans was tailored to fit the story. ${ }^{15}$ Their roots were to be discovered in the Himalayas, from where people wandered to the north of Europe and lost their previous "quality." This degradation was mainly due to the process of mixing with other races. ${ }^{16}$

A brave man is - according to the adopted definition - a man with a muscular body, tall and fair-haired. ${ }^{17} \mathrm{~A}$ weak man is sick and therefore must be a coward. Such thinking - although aspiring to a scientific status - is characteristic of a fairy tale in which negative heroes usually are ugly, and the good ones are beautiful. Witches are old and have hooked noses, while princesses are white-skinned and slender.

The belief in the "real people" who live in a manner destined for man, carries all the signs of religion, not science. Faith in the existence of a flawless man who lived with accordance to his original nature, a view of his history as a story of a fall $(\sin )$, and his ability to rise again (salvation) - correspond to the ideas that

13 Ibid., p. 11.

14 According to Hitler, humanity was divided into three separate groups: the creators of culture, its carriers and destroyers. The Jews belonged to the latter. The conviction about the danger of the "Jewish epidemic" was so powerful that it allowed the Nazis to remain completely blind to the facts such as that in the period preceding the war, 30\% of German Nobel laureates were Jews, the "culture destroyers."

15 The history of this institute can be used to study how far scientific work - some of Ahnenerbe's scientists have really solid achievements - can be politicized against their vocation.

${ }^{16}$ H. Pringle, Master Plan, p. 164.

17 Uzarczyk sums up Hans Gunther's propaganda thesis stating: "The Nordic type was tall and slim, with a narrow and elongated skull, a narrow face with a prominent beard and retracted bony jaws, a straight nose, sometimes slightly raised, and relatively long. Arch eyebrows were narrow, eyes blue, skin pink, hair delicate and straight to slightly wavy, gold-blond color. In terms of psychic properties, first and foremost is entrepreneurship the sense of justice, self-control, a strong sense of honor, love for truth and freedom, courage, and perseverance."-K. Uzarczyk, Podstawy ideologiczne higieny ras i ich realizacja na przykładzie Ślaska w latach 1924-1944, Toruń 2003, p. 129. 
can be found in many religions. What is specific for eugenic "faith" is the belief that human rebirth is possible not through the effort of the supernatural, but biology. The rebirth is to be achieved not through the soul but through the work of bio-technologists. This cult, like so many religious cults, has consumed a large number of sacrifices.

\section{Results of the Realization of the Myth}

Heinrich Himmler did not only make sure that the myth of warlords had "scientific" foundations, but he has also created the administrative body aiming at the practical realization of the myth. In 1935 he founded an institution Lebensborn, an SS organization whose goal was to promote the population policy in Germany. Initially, it was supposed to be a unit coupling people - just as Campanella wanted it in his City of the Sun - thus realizing the idea of the planned birth of real geniuses. However, due to the fear of public opinion, which at the time may not have accepted this "brave" idea, its official aim was "the accumulation of the Aryan blood." Let us see how it looked in practice.

The Lebensborn ${ }^{18}$ was the birth house for selected mothers. Buildings were located both in Germany (nine) and occupied countries (eleven). Lebensborn was, first and foremost, a place where pregnant unmarried "Aryan" women were offered help. The houses offered shelter during the prenatal period. They were also used by pregnant wives of the SS men. In Lebensborn's buildings, women not only gave birth but could live there during the first month after childbirth. They were provided with food and shelter. In case of any other parental problems, the organization helped to place children in "Aryan" foster families.

Nazis established this organization with their military plans in view too. They knew that incoming war was going to take a heavy toll on the German population and that Germany would lose many men of reproductive potential. So they have created a space where the man of ability could reproduce before going to war. In 1939 Himmler called the SS men for engagement in the process of reproduction. ${ }^{19}$

In 1933, abortion was completely banned in Germany. It can be said that Lebensborn was set up to make sure that this policy will be respected. An assistance extended to unmarried, pregnant "Aryan" women was supposed to result in, at least to some extent, social acceptance of single mothers. In this way they wanted to create a new moral climate in which giving a birth to an illegitimate but "valuable" child would be undeniably good for the whole community. Begetting such a child, despite the circumstances, was presented as a desired moral act and as a fulfilment of a duty to the state. ${ }^{20}$

${ }^{18}$ In literal translation it means "the source of life." This German word meaning the described institution does not have its equivalent in Polish language. In the literature concerning this phenomenon the word is used in its original form-in German.

${ }^{19}$ D. Schmitz-Kster, W imię rasy: dzieci dla Fürera-mity i rzeczywistość, transl. R. Wojnakowski, Warszawa 2000, p. 43.

${ }^{20}$ Ibid. 
The question arises whether the moral climate around unmarried mothers has indeed changed at that time. An answer is that it did but only partially. In the Lebensborn buildings the wives of the SS men and selected women who were able to show that they and child's fathers are both Aryan, side by side, gave birth to Aryan children. ${ }^{21}$ And despite the fact that having an illegitimate child was a shame, giving birth to an "Aryan" child was supposed to compensate for it. If it did, the compensation was not complete since unmarried mothers still felt "worse" than the SS wives. The new moral climate surrounding the extramarital birth of a child did actually occur but was more present as a declaration than as a real change in the interpersonal relations. For example, the information about the fathers-married or unmarried men having illegitimate children - was kept by the secret police offices in complete secrecy.

Ultimately bourgeois morale did not allow the institution appointed by Himmler to perform the function of a breeder; there were no arranged couples who would have sex merely for procreation purposes. Its activity was limited to protecting conceived children of Aryan origins. It is estimated that around 18,000 children were born in Lebensborn's homes. It is worth pointing out, however, that although these houses helped women who were in a difficult life situation, they remained part of the criminal activity of the nation-state, as an antidote to the existence of concentration camps. People were killed in the concentration camps, while in the Lebensborn houses they were born in order to balance for the loss in human material.

The most important thing is that this social policy was pursued in accordance with the myth of the existence of strong men who have fallen but may rise again. Brave Himalayan individuals leaving India travelled a long way to geographic Germany, preserving the "spark of genius." This was noticed and cherished by Nazi anthropologists. By sifting the wheat from the chaff, performing selections, they made possible - in their opinion - the (biological) rebirth of the real mankind. This operation had its priests and the place of worship. The birth of a child was an act of initiation, an act of entering into the new noble community. Sexual purity was replaced by the purity of the breed. Which does not mean that procreation ceased to have borders: they were established. Something special about them was that they were considered to be exclusively biological.

A contemporary example of the uninterrupted realization of the myth mentioned in this article is an institution commonly known as the Nobel Prize Sperm Bank, established in the 1980s in the United States. This institution is linked with Lebensborn's homes through its purpose. Similarly to the Nazi agenda, the bank is supposed to help humanity rejuvenate itself, preventing degradation of the human genetic material. And just like the Nazis were concerned with "enucleating" and sowing the "sparks of genius," the creator of this bank, Robert Graham, was concerned with "good genes." 22

21 This procedure was to examine the genealogy of both parents in terms of their "racial purity."

${ }^{22}$ D. Plotz, The Curious History of Nobel Prize Sperm Bank, New York 2006, p. 28. 
Although the American millionaire was not, like Himmler, a racist, the purpose of his actions was the same: to improve humanity by multiplying the best specimens. Graham's approach indicates a similar vision of history glorifying the past, sees the process of degradation, and finally brings out the vision of happiness as returning to something "real" and original. Those two views are alike, but the Himalayan men who form Nazis' vision were replaced in Graham's vision by the Cro-Magnon people. They have created a great culture in virtue of their qualities. They were recognized as the carriers of the greatest genes, which were not entirely lost and which still can, and must be recovered. The difficulty was that the progress in agriculture and "mass feeding," caused the increase in the number of the "weak," "stupid" and "lazy" people. ${ }^{23}$

Reproducing the best specimens was, according to Graham, the only remedy for the degenerated mankind. The exceptionally valuable humans (male, of course), having a wife or a constant partner and being constantly busy, have only a few children or none. It caused catastrophic demographic consequences. Graham claimed that the remedy was semen donation. It opened up a completely new horizon for biological fatherhood. But only the chosen ones qualified as donors. Initially, Graham thought that they should be graduates of military academies. Later, however, he acknowledged that Nobel Prize laureates were the most highly skilled individuals. He only meant those from the field of natural sciences. For him, humanists, artists, politicians, etc. are not particularly valuable. ${ }^{24}$

He has not succeeded in reproducing desired descendants. Graham was very disappointed by that fact. Only three Noble Prize winners have donated their semen and no woman was impregnated with it. All of 215 children born of the sperm collected in the bank were children of people who, although not the Noble Prize winners, were "successful" in Graham's eyes (this was not known to women applying for sperm from the sperm bank). According to research, those children did not achieve any spectacular success in their adult life, nor became an elite the creator dreamed of. They have led more or less successful lives, and despite having some abilities (in one case quite significant) none of them became known in scientific societies. Similarly to the children from Lebensborn's houses, they were unhappy not knowing their biological fathers. There was also another type suffering involved - one of the donors (fathers) felt a great void caused by not having any contact with their own children. Also, the husbands of women fertilized by artificial insemination suffered. After the child was born, they found themselves outside the family which from now on consisted only of the mother and her biological child. Many marriages fell apart.

\section{Conclusion}

It is clear that the success of eugenic thought appeared in a specific period of contemporary history. Formation of eugenics law in different countries occurred in a similar historical moment. It is possible to draw a graph of the increasing in-

\footnotetext{
${ }^{23}$ Ibid., p. 38 .

${ }^{24}$ Ibid., p. 60.
} 
terest in eugenic ideology, a period of fascination leading to a moment of interest extinguishment. This phenomenon is similar in the different countries in which it occurred. It is peculiar that the countries differ both economically and politically. They have different literary traditions, religions and historical past. Each of those countries differently defines its "social margin" to which the eugenic law is supposed to apply. The excluded groups differ. That raises the question of what was so attractive in eugenic thinking that despite those differences it was accepted by so many countries? I claim that eugenics offers a particular way of thinking which appears to be attractive regardless of the social group it is presented to. Somehow, it always finds many followers. And even if the ideology is in decline today, it still has its supporters.

In this article, I have attempted to answer the question of why eugenics was so widespread. I suggest that its popularity has its source in a myth of religious character. According to the myth, humans were once divine but then degenerated. And through the history they were struggling to return to the original state, to regain their "lost paradise." Eugenics pretends to be of a scientific character, but, just as any other religion, it aims eventually to give hope for a better future.

The eugenic myth creates a tempting vision glorifying past of particular people and the whole of humanity. It envisions humans as "good people" living "good life" in the past the way it should be lived. It is easy to re-awaken our longing for the time when man has not yet fallen and lived in harmony with nature, whatever it means. Often unknowingly, we share the belief that man has fallen under the pressure of bad living conditions. That resulted in a fall. The fall was caused by the development of our civilization we perceive as artificial, which crept into our natural life and corrupted it. ${ }^{25}$ The more our life departs from what we would call the natural life, the more attractive it is for us. We are striving for a simple life as composed exclusively of those activities only sustaining our existence. The vision of eugenic paradise is tempting. A distinguishing feature of eugenics is a need to get rid of those who are not like rest who are "better." This vision perfectly fits into the universality of the opinion that the world is corrupted by defective people. Without them, life can return to the desired form. The attractiveness of eugenics comes directly from the kind of remedy it offers to restore human beings after the fall. It perfectly fits the expectations of modern man who understands that suffering is (or should be) something easily and effortlessly removed (like a headache eliminated by pills). If we take a look at the history of culture, myths, religious visions or literature, we will find over and over again visions of a man endowed with divine qualities or godlike ones. This belief is a part of idealization we are strongly inclined to. We idealize the past of mankind by creating a vision of paradise where human life and the norms he observes are simple. We wish to realize this ideal. The more imperfect the world around us is, the easier for us it is

${ }^{25}$ Many eugenics supporters saw the recovery of "racial vigour" as a remedy for many industryrelated problems, such as overpopulation. Cf. P. Weidlling, "Krytycy, komentatorzy i przeciwnicy eugeniki 1880-1950," [in:] Eugenika-biopolityka-państwo: z historii europejskich ruchów eugenicznych, M. Gawin, K. Uzarczyk (eds.), Warszawa 2010, p. 50. 
to convince ourselves that it does not have to be that way, that it can be improved. However, the process of restoration of man to his original glory is obviously difficult, complex or even well-nigh impossible. Even the greatest optimists acknowledge that. And it is precisely in this that consists the attractiveness of eugenics lies; it offers effortless rejuvenation of humanity, nearly instant, and happening within labour wards. Moreover, eugenics promises that man par excellence can return, and at the same time we shall lose no good things offered to us by civilization, nothing from the comfort of our lives. Is there anything more attractive than a renaissance of a human being offered as a simple medical solution?

\section{Bibliography}

Campanella T., The City of the Sun, transl. D. Donno, The Floating Press 2009. Gawin M., Rasa i nowoczesność: historia polskiego ruchu eugenicznego (18801952), Warszawa 2003.

Musielak M., Sterylizacja ludzi ze względów eugenicznych w Stanach Zjednoczonych, Niemczech i w Polsce (1899-1945), Poznań 2008.

Nietzsche F., On Genealogy of Morality, transl. C. Diethe, Cambridge 2007.

Plato, Republic, transl. B. Jowet, Seattle 2010.

Plotz D., The Genius Factory: Curious History of Nobel Prize Sperm Bank, New York 2006.

Pringle H., Master Plan: Himmler's Scholars and the Holokaust, New York 2007.

Schafft G., From Racism to Genocide: Anthropology in the Third Reich, Urbana-Chicago 2004.

Schmitz-Kster D., W imię rasy: dzieci dla Fürera-mity i rzeczywistość, transl. R. Wojnakowski, Warszawa 2000.

Uzarczyk K., Podstawy ideologiczne higieny ras $i$ ich realizacja na przykładzie Ślaska w latach 1924-1944, Toruń 2003.

Weidlling P., "Krytycy, komentatorzy i przeciwnicy eugeniki 1880-1950," [in:] Eugenika-biopolityka-państwo: z historii europejskich ruchów eugenicznych, M. Gawin, K. Uzarczyk (eds.), Warszawa 2010, pp. 49-64. 